\title{
Yliopistosairaaloiden kirjasto- ja tietopalveluita ei tule unohtaa sote-uudistuksessa
}

\author{
KIRSI LUOTO, TUULEVI OVASKA, JARMO SAARTI
}

\section{YLIOPISTOSAIRAALOIDEN TIETOHUOLTO}

Sairaaloiden lääketieteelliset käytännöt perustuvat tieteellisiin tutkimustuloksiin, näyttöön perustuviin menetelmiin ja vuosisatojen mittaiseen tietämykseen. Tämä on ollut perusta nykyaikaisille sairaaloiden käytännöille ja potilashoidolle. Yliopistolliset sairaalat ovat merkittävä tekijä sekä akateemisessa tutkimuksessa että opetuksessa. Tieteelliset tietopalvelut ja ajantasaiset aineistokokoelmat luovat perustan niin akateemisten toimijoiden kuin sairaalan muunkin henkilökunnan erityistarpeiden tyydyttämiseksi.

Työpaikkoina yliopistolliset sairaalat ovat klassisessa mielessä tietointensiivisiä ympäristöjä. Ne tarvitsevat tehokkaat tietopalvelut ja ajan tasalla olevat tietoaineistot. Terveystieteet tuottavat myös suurimman osan maailman tieteellisestä tutkimuksesta. Kiireisessä sairaalatyössä henkilökunta tarvitsee tarvitsevat ammattilaisten apua tiedon järjestämiseen, hankkimiseen ja löytämiseen. Lisäksi omatoimisuus eri tietojärjestelmien käytössä on nostanut esille tarpeen yhä enemmän opettaa ja ohjata käyttäjiä, joten opetus- ja ohjaustehtävien määrä ja merkitys kirjastoissa on kasvanut. $(1,2)$

Suomessa on pitkä perinne yliopistojen ja yliopistollisten sairaaloiden yhteistyöstä kirjastoja tietopalveluiden järjestämisessä. Monessa tapauksessa sairaaloiden kirjastot ovat olleet myös perustana yhteistyöalueiden tieteellisten kirjastojen rakentumisessa. (3).

Yliopistojen hallinnollinen asema uudistettiin vuodesta 2010 alkaen. Parhaillaan ollaan uudistamassa kansallista sosiaali- ja terveyspalveluiden järjestämistä. Nämä molemmat vaikuttavat sekä yliopistojen että sairaaloiden hallintomalliin tuomalla niihin yritysmäisiä piirteitä ja reunaehtoja, jotka vaikuttavat palveluiden tuottamiseen. (4).
Tieteelliset aineistot hankitaan nykyisin digitaalisesti ja niihin saadaan tarkoin määritelty käyttöoikeus. Kustantajat ovat tarkkoja siitä, että akateemiseen käyttöön akateemisilla hinnoilla hankittuja aineistoja ei käytetä kaupallisiin tarkoituksiin eikä organisaatioissa, joiden toiminta joko muistuttaa tai on aidosti liiketaloudellista. Sote-uudistuksessa on vaara, että sairaaloiden ja terveydenhuollon toiminta alkaa näyttää yritysmäiseltä ja silloin tietoaineistojen käyttö siirtyy vain niille henkilöille, joilla on suora linkki yliopistoyhteisöön: yliopiston opiskelijoille ja tutkijoille.

Päätimme selvittää kyselyllä Kuopion yliopistollisen sairaalan henkilöstön tieteelliseen tietohuoltoon liittyviä tarpeita nykytilanteessa ja muutokset huomioiden. Keskeisinä tavoitteina oli selvittää, onko akateemista ja terveydenhoitotyötä tekevien ryhmien välillä merkittäviä eroja ja mitkä ovat palveluihin liittyvät tarpeet. (5)

Perusteemana kyselyssä oli nykyisten palveluiden käytön analyysi. Ne jaoteltiin kokoelmiin, tutkimuksen ja julkaisemisen tukeen, henkilökohtaiseen palveluun, opetuspalveluihin ja ohjeisiin. Palveluista kysyttiin nykyistä käyttöä ja tulevaisuuden tarvetta. Lisäksi kerättiin avoimia vastauksia.

Kyselyyn saatiin 184 vastausta. Vastaajista 138 oli vain sairaalan palveluksessa ja 29 henkilöä sekä yliopiston että sairaalan palveluksessa. Vastaajista neljä oli vain yliopiston palveluksessa. Vastaajista 45 määritteli itsensä kliinikoiksi, 43 tutkijoiksi, 19 opiskelijoiksi ja seitsemän olivat muita käyttäjiä.

\section{YLIOPISTOLLISEN SAIRAALAN TIETOHUOLLON TARPEET}

Tämän vastaajajoukon perusteella voi esittää, että vastausten jakauma oli eri ryhmien välillä 
hyvin samanlainen. Lisäksi näyttää siltä, että jos vastaaja käytti jotakin tieteellisen kirjaston tarjoamaa palvelua, niin hän hyvin todennäköisesti käytti myös muitakin tarjottuja palveluita. Palvelutarjonta näyttää siis olevan toisiaan täydentävää, esimerkiksi henkilökohtaisia palveluita käyttävät käyttivät yleensä - noin puolet - laajaa tarjontaa: henkilökohtaista neuvontaa, tiedonhakupalveluita ja aineiston jakelua. Palveluiden tarve näytti korreloivan myös niin, että nyt käytettyjä palveluita käytetään myös tulevaisuudessa.

Aineistossa ei ollut myöskään merkittävää eroa eri ryhmien välillä eniten käytetyissä palveluissa. Suurin ero oli digitaalisten aineistojen etäkäytössä, bibliometriikkapalveluissa ja tietopalveluissa. Erityisesti bibliometriikkapalveluiden käyttö oli vähäisempää kuin aineistojen etäkäyttö. Tämä on ymmärrettävää, koska tutkimusjulkaisemiseen liittyvät bibliometriikkapalvelut todennäköisesti kiinnostaa vain niitä toimijoita sairaalassa, jotka julkaisevat tutkimustuloksiaan.

Kirjaston tilojen ja kirjaston tarjoamien opetusten ja opastusten käyttö oli selkeästi vähäisempää kuin edellä mainittujen palveluiden. Tilojen käyttöä selittää se, että entistä enemmän palvelut ovat siirtyneet verkon kautta käytettäväksi. Opetusten ja ohjeiden vähäisen käytön määrää tulee analysoida tarkemmin: onko kysymys palveluiden markkinoinnin epäonnistumisesta vai siitä, että käyttäjät kokevat, etteivät tarvitse näitä palveluita? Aineiston hankintaan liittyvät palvelut olivat vähiten tunnettuja.

Kokoelmien tärkeys näkyi myös avointen vastausten kommenteissa, niistä tuli runsaasti palautetta. Kirjat ovat edelleen tärkeä lähde osaamisen kehittämisessä, lisäksi e-aineistot ja niiden etäkäyttö on keskeinen resurssi kaikille käyttäjille. Myös tietopalvelut mainittiin usein. Kaikista palveluista saatiin kommentteja, joten näyttää siltä, että kirjaston tarjoamat peruspalvelut ovat sekä tarpeellisia että käytettyjä.

Palveluiden tulevaisuudesta annettu palaute näyttää siltä, että vastaajat ovat tyytyväisiä nykyisiin palveluihin ja tarvitsevat niitä jatkossakin. Eniten mainintoja saivat henkilökohtainen palvelu ja tiedonhakutaitojen opetus. Myös palveluiden asiantuntevuutta arvostettiin ja sitä, että asiantuntemusta ja opastusta on myös uusista ja ajankohtaisista asioista tieteellisessä julkaisemisessa.
Yleisessä palautteessa vastaajat arvostivat kirjaston palvelun asiantuntemusta ja ystävällisyyttä. Lisäksi sujuvat ja joustavat prosessit olivat vastaajille tärkeitä, erityisesti aineistojen liikkuminen kirjaston eri yksiköiden välillä (6). Vaikka etäkäyttö oli keskeistä, niin myös henkilökohtaista palvelua ja kirjastotiloja tarvittiin jatkossakin. Kirjasto nähtiin myös keskeisenä välineenä ammatilliselle kehittymiselle. Vastaajat toivatkin esille sen, että yliopistollisessa sairaalassa tulee olla tieteellinen kirjasto, joka tukee sairaalassa tehtävää kliinistä tutkimusta ja osaamisen kehittämistä.

"KYSin tieteellisen kirjaston palvelut ovat erinomaisia. Palvelu on hyvää ja nopeaa. Yliopistosairaalassa tulee olla oma tieteellinen kirjasto."

Palveluista vastaajat arvostivat erityisesti opetusta ja halusivat erityisesti tutkimusta tukevien erityistaitojen opetusta. Myös kirjaston tilojen ja erityisesti niissä käytettävien tietokoneiden tarpeellisuudesta tuli palautetta.

"Minusta on erityisen tärkeää että [palvelut] säilyvät ja kehittyvät. Myös fyysistä kirjastoa tarvitaan (ei ainoastaan virtuaalista).”

Vastauksista voi päätellä myös selkeästi sen, että kirjaston viestinnän tulee olla aktiivisempaa. Jotkut vastaajat eivät tienneet ollenkaan kirjaston tarjoamista palveluista ja toisille oli hankalaa löytää tietoa kirjaston palveluista tietoverkosta. Quesenberry ym. (7) ovatkin esittäneet, että kirjastojen palveluiden tulisi integroitua paremmin arkipäivän rutiineihin kaikissa työtehtävissä. Lisäksi he korostavat tarvetta strategioille, joilla saavutetaan mahdollisimman helppokäyttöiset muodot tietoaineistojen käytölle ja tunnistetaan ne tavat ja muodot, joilla käyttäjät hankkivat itselleen tietoa palveluista ja resursseista (7).

Ajanpuute ja kiire ovat keskeisimmät esteet kirjastonkäytölle, kuten huomataan seuraavasta kommentista:

"Minulla ei ole ollut mahdollisuutta tutustua palveluihin ja kokoelmiin. Työaikana minulla ei ole aikaa perehtyä kirjaston tarjoamiin ohjeisiin sairaalan sisäisessä verkossa.” 
Se, että henkilö on tietoinen kirjaston tarjoamista ohjeista, on hyvä merkki, mutta näyttää siltä, että itsensä kehittämiseen tulee olla mahdollisuus varata myös työaikaa.

\section{TIETOHUOLTO KESKEISENÄ YLIOPISTOLLISEN SAIRAALAN TOIMINTONA}

"On keskeistä, että kirjasto pystyy tiedottamaan aktiivisesti kokoelmistaan ja palveluistaan. Tässä ei ole kyse vain informaation jakelusta tai markkinoinnista vaan siitä, että kirjasto kehittää palveluitaan sairaalan tarpeiden suuntaisesti ja samalla etsii tukijoita ja yhteistyökumppaneita vahvistamaan yhdentymistä" (8). Osa kyselyn kysymyksistä osoittautuikin enemmän markkinoinnin välineiksi, joilla pystytään kertomaan vähemmän käytetyistä tai huonosti tunnetuista palveluista. Vastaukset antavat selkeästi myös työkaluja sen perustelemiseen, ettei sote-uudistuksessa tule unohtaa tieteellisten kirjasto- ja tietopalveluiden kehittämistä ja niiden olemassaolon ehtojen turvaamista vähintään yliopistollisissa sairaaloissa.

Kysely varmisti myös hypoteesin siitä, että yliopistollisen sairaalan kaikki toimijat tarvitset korkealaatuisia kirjasto- ja tietopalveluita. Keskeisin resurssi on ajantasainen ja tieteellisesti luotettava digitaalinen aineistokokoelma. Lisäksi näyttää siltä, että oletus siitä, että sairaalan henkilöryhmät jakautuisivat enemmän erikoispalveluiden käytössä, on väärä: kaikkia tieteellisen kirjaston tarjoamia palveluita käytettiin kaikissa ryhmissä.

Johtopäätöksenä voidaan esittää, että niissä sairaaloissa, joissa tehdään tieteellistä tutkimusta ja opetusta, tietokäyttäytymisen kulttuuri on hyvin samankaltaista kuin muissakin tutkimukseen perustuvissa toimijoissa. Riippumatta työtehtävistä ja rooleista, kaikki sairaalan henkilöstön jäsenet tarvitsevat tutkittua tietoa ja siihen liittyviä palveluita jokapäiväisessä työssään ja osaamisensa kehittämisessä. Tästä seuraa, että sairaaloissa on selkeä tarve ammattimaisille akateemisille kirjasto- ja tietopalveluille eikä pelkkään itsepalveluun perustuva ajattelu tuota haluttua lopputulosta. Hyvät kirjasto- ja tietopalvelut ovat myös työnantajan kilpailuvaltti tulevaisuuden työmarkkinoilla.

K. Reducing library space can promote the shift from storage of print-collections towards a learning-centre without limiting the access to information. Library Management 2015 11/09; 2018/01;36(8):685-689.

(7) Quesenberry AC, Oelschlegel S, Earl M, Leonard K, Vaughn CJ. The Impact of Library Resources and Services on the Scholarly Activity of Medical Faculty and Residents. Med Ref Serv Q 2016 07/02;35(3):259-265.

(8) Macdonald K. Collaborative Partnerships for Library Services: Examples From a Hospital Library. Journal of Hospital Librarianship 2015 10/02;15(4):365-372.

\section{KIRSI LuOTO}

FT, tutkimuspäällikkö

Pohjois-Savon sairaanhoitopiiri

Kuopion yliopistollinen sairaala

Advances in Librarianship Bingley: Emerald; 2013. p. 225-246.

https://doi.org/10.1108/S0065-

2830(2013)0000036011

(5) Halkoaho A, Luoto K, Ovaska T, Saarti J, Selander T. Supporting the medical research and daily work at the hospital - analysing the library and information services at the Kuopio University Hospital. Journal of EAHIL 2018;14(1):9-14.

(6) Haapanen M, Kultamaa P, Ovaska T, Salmi

\section{TuUlevi Ovaska}

$F M$, erityistietoasiantuntija

Itä-Suomen yliopisto

JARMO SAARTI

FT, dosentti, kirjaston johtaja

Itä-Suomen yliopisto 